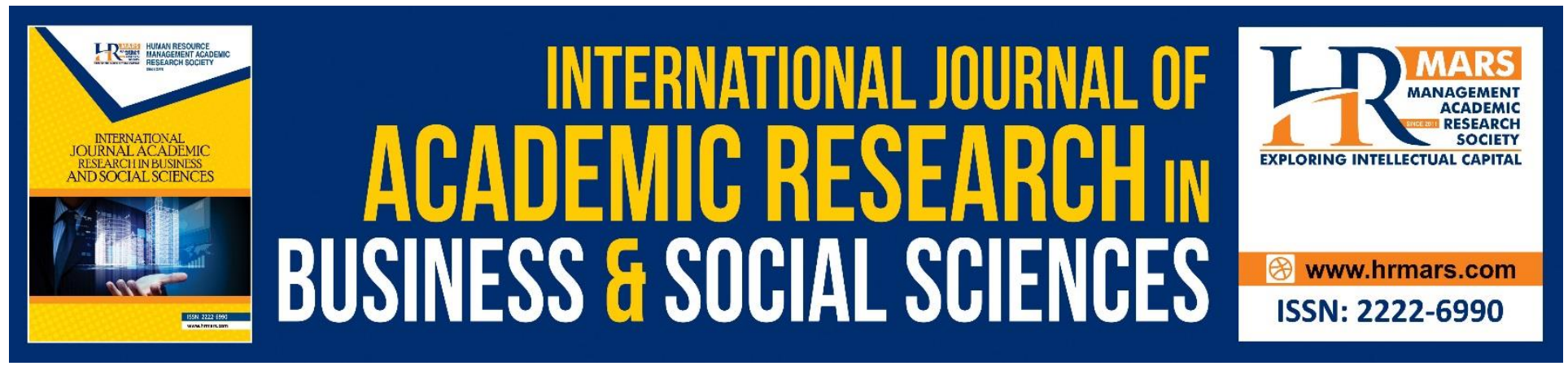

\title{
Acceptance and Adequacy of Water Supply Among Flood Victims at the Temporary Evacuation Centres in Kuala Krai, Kelantan, Malaysia
}

Koh Liew See, Nasir Nayan, Hanifah Mahat, Yazid Saleh, Mohmadisa Hashim

To Link this Article: http://dx.doi.org/10.6007/IJARBSS/v10-i10/8266

DOI:10.6007/IJARBSS/v10-i10/8266

Received: 20 August 2020, Revised: 06 September 2020, Accepted: 30 September 2020

Published Online: 23 October 2020

In-Text Citation: (See et al., 2020)

To Cite this Article: See, K. L., Nayan, N., Mahat, H., Saleh, Y., \& Hashim, M. (2020). Acceptance and Adequacy of Water Supply Among Flood Victims at the Temporary Evacuation Centres in Kuala Krai, Kelantan, Malaysia. International Journal of Academic Research in Business and Social Sciences, 10(10), 1043-1053.

Copyright: (c) 2020 The Author(s)

Published by Human Resource Management Academic Research Society (www.hrmars.com)

This article is published under the Creative Commons Attribution (CCBY 4.0) license. Anyone may reproduce, distribute, translate and create derivative works of this article (for both commercial and non-commercial purposes), subject to full attribution to the original publication and authors. The full terms of this license may be seen at: http://creativecommons.org/licences/by/4.0/legalcode

Vol. 10, No. 10, 2020, Pg. 1043 - 1053

http://hrmars.com/index.php/pages/detail/IJARBSS

JOURNAL HOMEPAGE

Full Terms \& Conditions of access and use can be found at

http://hrmars.com/index.php/pages/detail/publication-ethics 


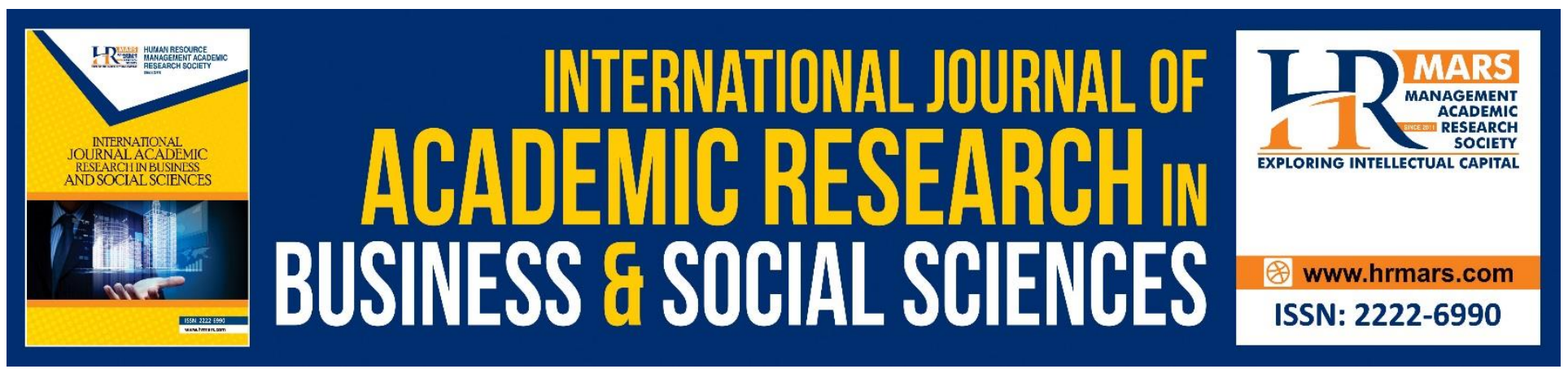

\title{
Acceptance and Adequacy of Water Supply Among Flood Victims at the Temporary Evacuation Centres in Kuala Krai, Kelantan, Malaysia
}

\author{
Koh Liew See, Nasir Nayan, Hanifah Mahat, Yazid Saleh, \\ Mohmadisa Hashim
}

Department of Geography and Environment, Faculty of Human Sciences, Sultan Idris Education

University Malaysia

\begin{abstract}
This article discusses the analysis of water supply acceptance and adequacy among flood victims at the Kuala Krai Temporary Evacuation Centres (TECS) in Kelantan, Malaysia. This study applied a quantitative approach using questionnaire. A total of 300 flood victims were randomly selected. The aspects being measured were the types of water resource acceptance as well as the adequacy of water supply according to four main types of domestic activities at the TECs, namely drinking, cooking, bathing and washing. The analysis used was descriptive analysis, a cross-tabulation test to assess the relation of water supply adequacy to respondents' profile and the selected TECs. The findings showed that the bottled/mineral water acceptance by the flood victims was insufficient for drinking and cooking purposes, while the acceptance of rainwater as a water supply for bathing and washing was sufficient. The findings also show that the water supply was insufficient for drinking (84.96\%), cooking $(85.84 \%)$, bathing $(61.06 \%)$ and washing $(53.10 \%)$ for female compared to male. Similarly with the married respondents who claimed that water supply was inadequate for all types of domestic activities such as for drinking (74.29\%), cooking $(66.29 \%)$, bathing $(53.71 \%)$ and washing (50.29\%), compared to the unmarried and widowed. Based on TECs, more attention should be given to the water supply at SMK Laloh and SK Kuala Gris as the majority of respondents $(>52.17 \%)$ stated that the water supply was insufficient for carrying out all domestic activities, compared to SMK Sultan Yahya Petra 2 and SMK Manek Urai Lama. Therefore, water supply management during flood disasters is urgently needed to deal with insufficient water supply issues by increasing the efficiency of water supply distribution so that the Kuala Krai flood victims can get sufficient water supplies at the TECs despite being hit by major floods.
\end{abstract}

Keywords: Acceptance, Adequacy, Water Supply, Flood

\section{Introduction}

A clean water supply plays an important role as a major resource in human life to carry out domestic activities, especially for cooking, drinking and washing. Therefore, management plays an important 
role to ensure the quality of clean water supplies and sufficient for user consumption. However, ensuring the adequacy of clean water supplies during floods is difficult if there is no systematic management to ensure that clean water supplies are continuously distributed during flood disasters. This is due to the rising of flood water levels which causes damage to the water supply facilities and water treatment plant equipment (Sharad et al., 2007; Abbas \& Routray, 2014; Linscott, 2007; Shimi et al., 2010; Mahmood, 2004) resulting in water supply being shut off. Such condition will result in flood victims not having sufficient clean water supplies during floods, which prompts the flood victims to use water with unknown hygienic status. Indirectly, many water-borne infectious diseases occur during floods such as malaria, cholera, eye diseases and skin diseases (Few et al., 2004; Abbas \& Routray, 2014).

The monsoon floods have gained full attention in Malaysia, especially in the east coast of Peninsular Malaysia such as Kuala Krai, Kelantan. Among the areas under Kuala Krai District that are often exposed to floods are Kuala Krai town, Pahi, Manek Urai, Lela Jasa and Dabong as these areas are low areas situated along Sungai Kelantan. The main factor that causes the area to flood is the monsoon season heavy rain resulting in the overflow of Sungai Kelantan, Sungai Lebir and Sungai Galas (Department of Town and Country Planning, 2011). During floods, the water supply aspect is the issue that needs to be addressed by the authorities, especially those responsible for flood disaster management in Kuala Krai. It is important to ensure that the flood victims evacuated at the TECs are provided with clean and sufficient water supplies. However, the flood victims are often faced with the problem of insufficient water supply during floods. Due to the lack of clean water during flood, the flood victims have to resort to using water with unknown quality status such as flood water for domestic activities (Shimi et al., 2010).

This situation is evident when the Kuala Krai District was hit by a major flood in 2014 known as "Bah Kuning" (yellow flood) (Wan et al., 2015; Kamarul et al., 2015). The flood had caused the flood victims who were transferred to the temporary evacuation centres (TECs) to be disconnected from the authorities to the extent that it disrupted the supply of basic needs for the flood victims due to the increase in river water levels, including clean water supply. The highest levels of river water recorded that year for Sungai Galas in Dabong was 46.47 meters (dangerous level: 38 meters), Sungai Lebir in Tualang was 42.17 meters (dangerous level: 35 meters) and Sungai Kelantan was 34.17 meters (dangerous level: 25 meters) (eBanjir Negeri Kelantan, 2015). These difficulties had caused the flood victims to face insufficient water supply at the TECs and exposed them to water-borne diseases if they were to use contaminated water such as flood water for domestic activities. The major flood event in 2014 was reported to have 458 cases of leptospirosis occurring in Kelantan (Ministry of Health Malaysia, 2015). Because of that, the aspect of water adequacy plays an important role in ensuring that the flood victims can carry out their usual domestic activities at the TECs. Therefore, this article will discuss the acceptance and ade quacy of water supply as well as the relation of water supply adequacy based on the profiles of the respondents and the TECs.

\section{Study Area}

This study was conducted in Kuala Krai District, Kelantan, Malaysia, focusing on four selected TECs, namely SMK Sultan Yahya Petra 2, SMK Manek Urai Lama, SMK Laloh and SK Kuala Gris (Figure 1). This is because the four TECs were the TECs affected during the flood and had the highest number of flood victims. 


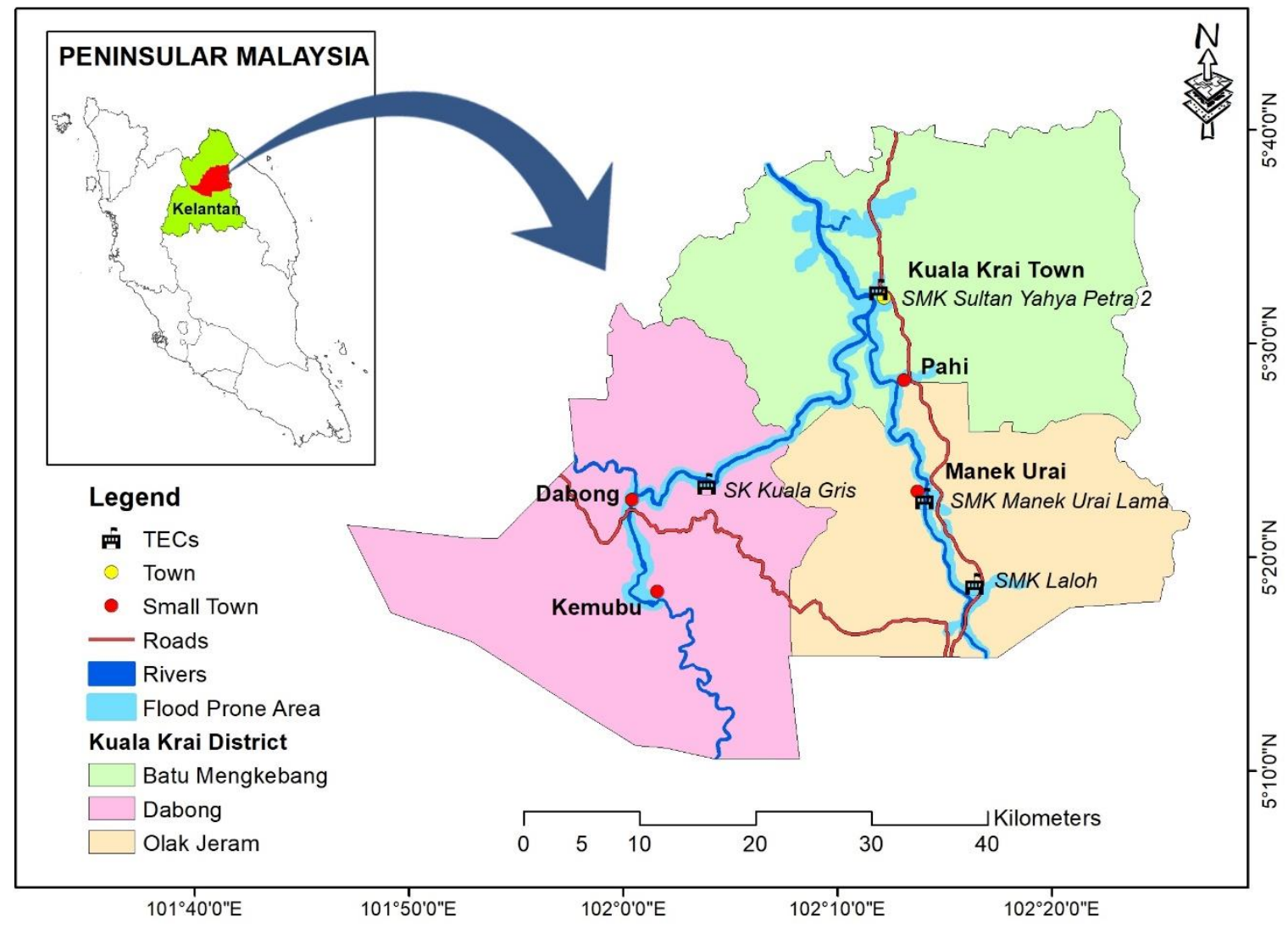

Figure 1. Location of Selected TECs

\section{Research Methodology}

The research approach applied was quantitative. This study used a questionnaire to measure water supply acceptance and adequacy among the flood victims at the selected TECs. Respondents live in selected TECs approximately a week more. The questionnaire consisted of three sections, namely respondents' background (Section A), types of water resource acceptance (Section B) and water supply adequacy based on four main domestic activities at TECs which are drinking, cooking, bathing and washing (Section C). Content validity was carried out on the items constructed with the help of the experts in statistics and hydrology to see the extent to which the measurements made represent the content needed to be measured (Chua, 2014). Besides, the reliability of the research instrument was also measured to assess the stability or accuracy of the instrument constructed.

The results of the pilot study on 30 respondents showed that the Cronbach's alpha reliability coefficients calculated using SPSS (Statistical Package for Social Science) were 0.831 with four items in Section B and 0.907 with four items in Section C. These values explain that the reliability of the research instrument is high and satisfactory. Determination of the sample size was based on Krejcie and Morgan (1970) which involved 300 people from 1,020 families of flood victims who were transferred to four selected TECs. Table 1 shows the division of samples for four selected TECs. The sampling method used was simple random sampling. The analysis methods used in this study were descriptive analysis and cross-tabulation test. The cross-tabulation test was used in this study to identify water supply adequacy according to respondents' profiles such as the respondents' gender 
INTERNATIONAL JOURNAL OF ACADEMIC RESEARCH IN BUSINESS AND SOCIAL SCIENCES Vol. 10, No. 10, 2020, E-ISSN: 222 2-6990 @ 2020 HRMARS

and marital status. This is due to reason that the two aspects play an important role in examining the adequacy of water supply for domestic activities of the flood victims transferred. Besides, this test was also applied in examining the adequacy of water supply at four selected TECs. It would also be able to find out more about the types of water supply that need to be distributed to the flood victims at the TECs.

Table 1. Sample Sizes for Four Selected TECs

\begin{tabular}{|l|c|c|}
\hline TECs & Population & Sample Size \\
\hline SMK Sultan Yahya Petra 2 & 288 & 85 \\
\hline SMK Manek Urai Lama & 450 & 132 \\
\hline SMK Laloh & 79 & 23 \\
\hline SK Kuala Gris & 203 & 60 \\
\hline Total & 1,020 & 300 \\
\hline
\end{tabular}

\section{Findings and Discussion}

\section{Profile of Respondents}

The majority of the respondents were male (62.30\%) and the rest were female (37.70\%). The survey results showed that most respondents were married (58.35\%), followed by single status (31.35\%) and widowed status (10.30\%).

\section{Acceptance and Adequacy of Water Supply at the TECs}

Water supply use at TECs varies for every domestic activity such as drinking, cooking, bathing and washing. This section will discuss the types of water supply acceptance and adequacy at TECs. Figure 2 shows the types of water supply acceptance and adequacy for drinking purpose. The highest type of water supply acceptance for drinking was from bottled/mineral water at $59.27 \%$, followed by tank water (20.53\%) and rainwater (20.20\%). However, most respondents stated that the water supplies for drinking were insufficient with a percentage value of $72.33 \%$. This situation shows that the majority of the flood victims consumed bottled/mineral water for drinking, but it was insufficient to cater for the flood victims at the TECs during flood disaster.
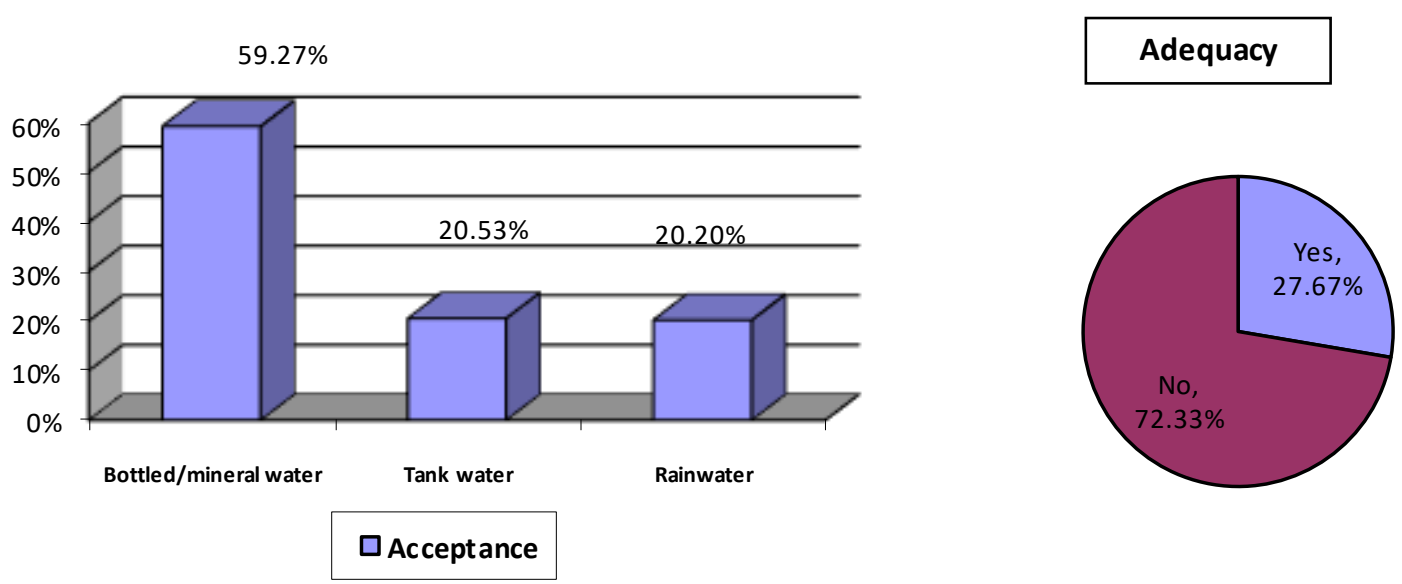

Figure 2. The Types of Water Supply Acceptance and Adequacy for Drinking Purpose 
Besides that, Figure 3 shows the types of water supply acceptance and adequacy for cooking purpose. Bottled/mineral water recorded the highest value for cooking use of $44.01 \%$, followed by tank water (28.48\%), rainwater (26.86\%) and flood water (0.65\%). $64.67 \%$ of the respondents stated that the water supplies for cooking purposes were insufficient. This situation explains that the use of bottled/mineral water for cooking was insufficient to accommodate the cooking activities among the flood victims at the TECs during flood disaster.
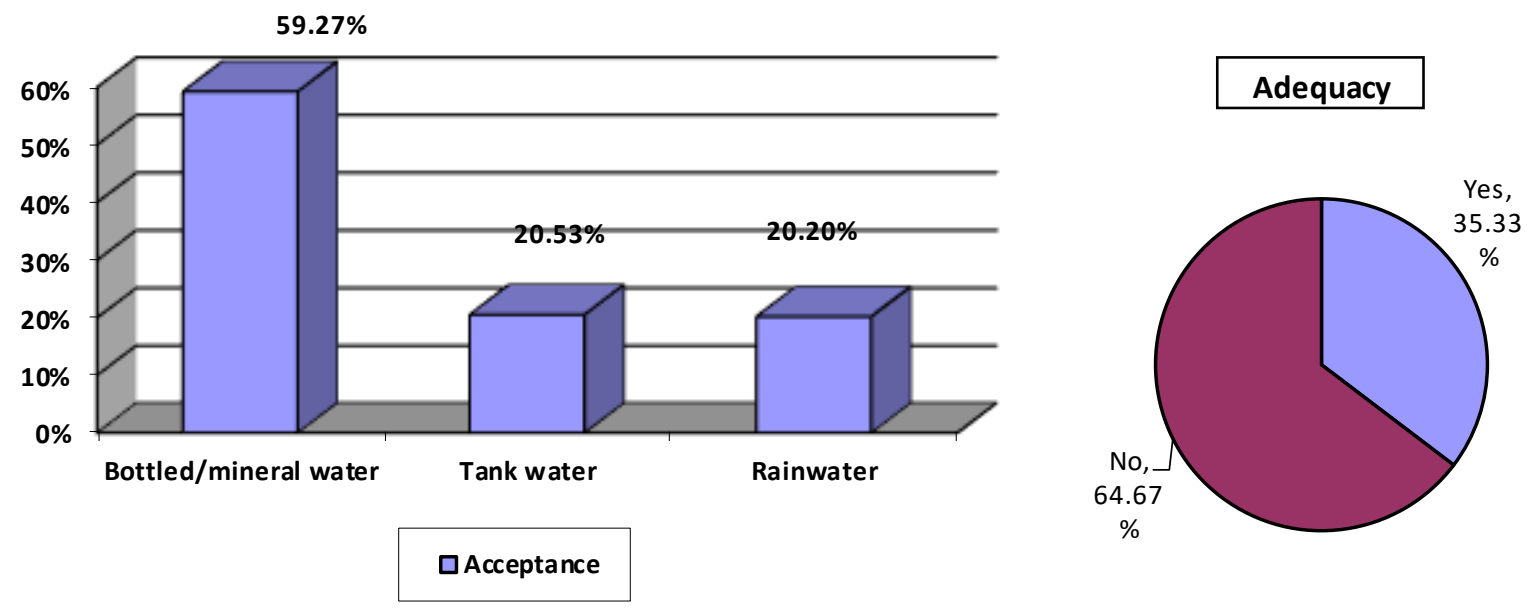

Figure 3. The Types of Water Supply Acceptance and Adequacy for Cooking Purpose

Figure 4 shows the types of water supply acceptance and adequacy for bathing purpose. The findings showed that most respondents used rainwater for bathing with a percentage value of $46.06 \%$, followed by tank water (37.85\%), bottled/mineral water (14.83\%) and flood water (1.26\%). In terms of adequacy, $51.00 \%$ of the respondents stated that the water supplies for bathing purposes were sufficient. This situation explains that most flood victims relied on rainwater for bathing and it was sufficient.
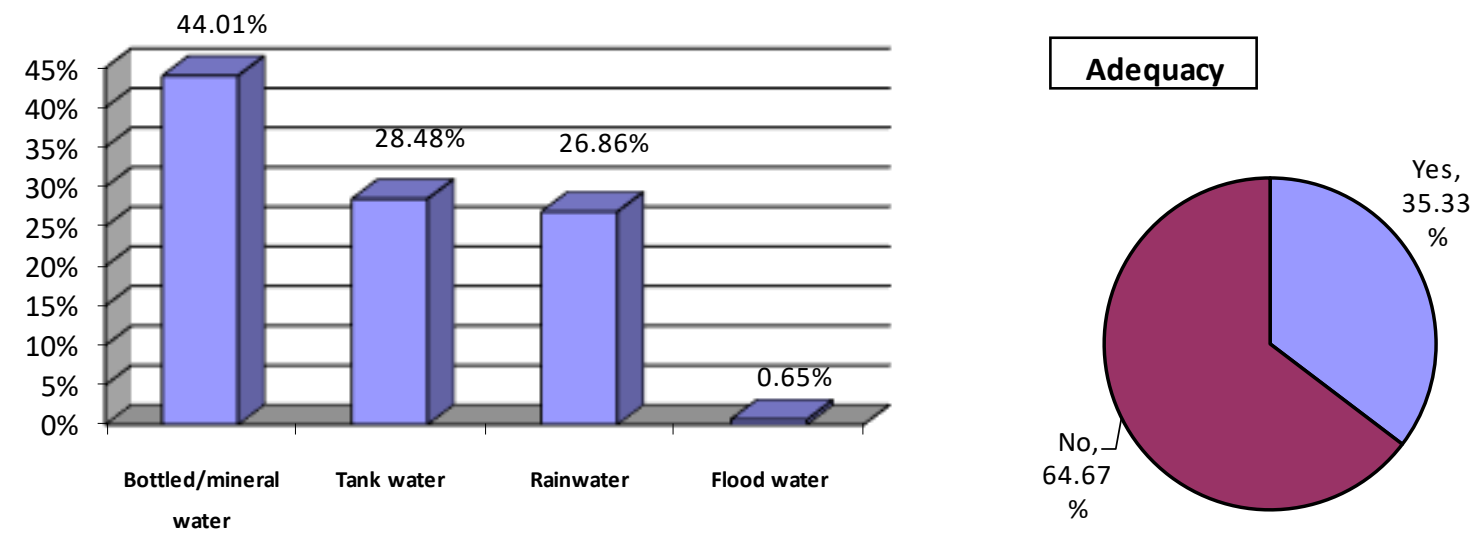

$\square$ Acceptance

Figure 4. The Types of Water Supply Acceptance and Adequacy for Bathing Purpose 
Meanwhile, Figure 5 shows the types of water supply acceptance and adequacy for bathing purpose. The results also show that most of the respondents used rainwater for washing which was $58.58 \%$, followed by tank water $(29.77 \%)$, bottled/mineral water $(9.71 \%)$ and flood water $(1.94 \%)$. The majority of the respondents stated that the water supplies for washing were sufficient with a percentage value of $55.33 \%$. This situation explains that most of the flood victims used rainwater for washing activities which was sufficient.
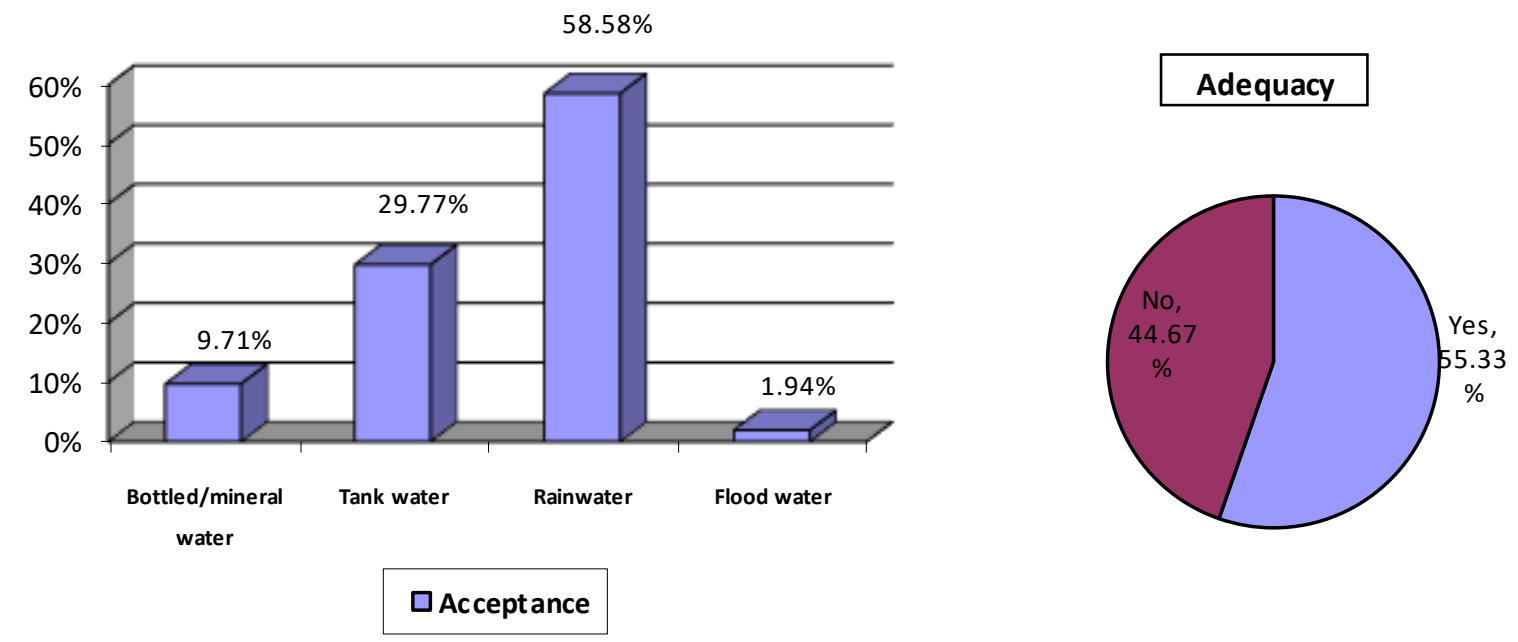

Figure 5. The Types of Water Supply Acceptance and Adequacy for Washing Purpose

Overall, the results of the analysis indicated that the bottled/mineral water acceptance by the flood victims at the TECs was insufficient for drinking and cooking purposes. The findings of this study showed that more water supply assistance are needed, especially bottled/mineral water from the responsible parties to help the flood victims to use clean and safe water for drinking and cooking. This is because the use of contaminated water during floods can affect the health of the flood victims and increase the risk of the spreading of water borne diseases (Bariweni et al., 2012; Shimi et al., 2010). However, the acceptance of rainwater as a water supply for bathing and washing at the TECs was sufficient. This is because rainwater is a water resource that is easy to be obtained during monsoon season.

\section{Cross-tabulation test of water supply adequacy among flood victims}

The results of cross-tabulation test in Table 2 show that most male respondents stated that water supplies were insufficient for drinking (64.71\%) and cooking (51.87\%) purposes, but there were enough water supplies for bathing (58.29\%) and washing (60.43\%). While the female respondents stated that water supplies were insufficient for all purposes including for drinking (84.96\%), cooking (85.84\%), bathing (61.06\%) and washing (53.10\%). This situation explains that the bottled/mineral water aid for drinking and cooking was insufficient for male and female. As for the use of rainwater for bathing and washing, it was sufficient for male but not enough for female. 
INTERNATIONAL JOURNAL OF ACADEMIC RESEARCH IN BUSINESS AND SOCIAL SCIENCES Vol. 10, No. 10, 2020, E-ISSN: $2222-6990$ C 2020 HRMARS

Table 2. Cross-Tabulation Test Between Gender and Water Supply Adequacy

\begin{tabular}{|c|c|c|c|c|c|c|c|}
\hline \multicolumn{2}{|c|}{ Water supply adequacy } & \multicolumn{4}{|c|}{ Gender } & \multirow{2}{*}{\multicolumn{2}{|c|}{ Total }} \\
\hline & & \multicolumn{2}{|c|}{ Male } & \multicolumn{2}{|c|}{ Female } & & \\
\hline & & $\mathrm{N}$ & $\%$ & $\mathrm{~N}$ & $\%$ & $\mathrm{~N}$ & $\%$ \\
\hline \multirow[t]{2}{*}{ Drinking } & Yes & 66 & 35.29 & 17 & 15.04 & 83 & 27.67 \\
\hline & No & 121 & 64.71 & 96 & 84.96 & 214 & 71.33 \\
\hline \multirow[t]{2}{*}{ Cooking } & Yes & 90 & 48.13 & 16 & 14.16 & 106 & 35.33 \\
\hline & No & 97 & 51.87 & 97 & 85.84 & 194 & 64.67 \\
\hline \multirow[t]{2}{*}{ Bathing } & Yes & 109 & 58.29 & 44 & 38.94 & 153 & 51.00 \\
\hline & No & 78 & 41.71 & 69 & 61.06 & 147 & 49.00 \\
\hline \multirow[t]{2}{*}{ Washing } & Yes & 113 & 60.43 & 53 & 46.90 & 166 & 55.33 \\
\hline & No & 74 & 39.57 & 60 & 53.10 & 134 & 44.67 \\
\hline
\end{tabular}

Note. $\mathrm{N}=$ frequency, $\%=$ percentage

According to the results of cross-tabulation test in Table 3 show that the respondents with single status stated that water supplies were insufficient for drinking (70.21\%) and cooking (61.70\%), but enough for bathing (57.45\%) and washing (64.89\%) purposes. As for the respondents who were married, they stated that water supplies were insufficient for all purposes including drinking (74.29\%), cooking (66.29\%), bathing (53.71\%) and washing (50.29\%). As for the widowed respondents, they stated that water supplies were insufficient for drinking $(67.74 \%)$ and cooking (64.52\%), but enough for bathing (58.06\%) and washing (58.06\%). This situation clearly shows that the respondents who had families required plenty of water supplies to accommodate the needs of family members at the TECs where bottled/ mineral water supplies were inadequate for drinking and cooking, and the use of rainwater was also inadequate for bathing and washing.

Table 3. Cross-Tabulation Test between Marital Status and Water Supply Adequacy

\begin{tabular}{|c|c|c|c|c|c|c|c|c|c|}
\hline \multirow{2}{*}{\multicolumn{2}{|c|}{ Water supply adequacy }} & \multicolumn{6}{|c|}{ Marital status } & \multirow{2}{*}{\multicolumn{2}{|c|}{ Total }} \\
\hline & & \multicolumn{2}{|c|}{ Single } & \multicolumn{2}{|c|}{ Married } & \multicolumn{2}{|c|}{ Widowed } & & \\
\hline & & $\mathrm{N}$ & $\%$ & $\mathrm{~N}$ & $\%$ & $\mathrm{~N}$ & $\%$ & $\mathrm{~N}$ & $\%$ \\
\hline \multirow[t]{2}{*}{ Drinking } & Yes & 28 & 29.79 & 45 & 25.71 & 10 & 32.26 & 83 & 27.67 \\
\hline & No & 66 & 70.21 & 130 & 74.29 & 21 & 67.74 & 214 & 71.33 \\
\hline \multirow[t]{2}{*}{ Cooking } & Yes & 36 & 38.30 & 59 & 33.71 & 11 & 35.48 & 106 & 35.33 \\
\hline & No & 58 & 61.70 & 116 & 66.29 & 20 & 64.52 & 194 & 64.67 \\
\hline \multirow[t]{2}{*}{ Bathing } & Yes & 54 & 57.45 & 81 & 46.29 & 18 & 58.06 & 153 & 51.00 \\
\hline & No & 40 & 42.55 & 94 & 53.71 & 13 & 41.94 & 147 & 49.00 \\
\hline \multirow[t]{2}{*}{ Washing } & Yes & 61 & 64.89 & 87 & 49.71 & 18 & 58.06 & 166 & 55.33 \\
\hline & No & 33 & 35.11 & 88 & 50.29 & 13 & 41.94 & 134 & 44.67 \\
\hline
\end{tabular}

Note. $\mathrm{N}=$ frequency, $\%$ = percentage

Besides that, the results of cross-tabulation test in Table 4 show that most respondents who were transferred to the TECs at SMK Sultan Yahya Petra 2 mentioned that water supplies were not enough for drinking (85.88\%) and cooking (68.26\%), but enough for bathing $(51.76 \%)$ and washing (84.71\%). Similarly, the respondents who were transferred to the TECs at SMK Manek Urai Lama 
INTERNATIONAL JOURNAL OF ACADEMIC RESEARCH IN BUSINESS AND SOCIAL SCIENCES

Vol. 10, No. 10, 2020, E-ISSN: 222 2-6990 @ 2020 HRMARS

stated that water supplies were insufficient for drinking (55.30\%) and cooking $(52.27 \%)$, but enough for bathing (67.42\%) and washing (65.15\%). In addition, the respondents who were transferred to SMK Laloh and SK Kuala Gris claimed that the water supplies were not enough for all purposes. These findings explain that the water supplies at SMK Laloh and SK Kuala Gris were inadequate for all domestic activities at the TECs during floods, especially the water supply aid. While at the TECS of SMK Sultan Yahya Petra 2 and SMK Manek Urai Lama, the inadequacy was only for drinking and cooking purposes.

Table 4. Cross-Tabulation Test between TECs and Water Supply Adequacy

\begin{tabular}{|c|c|c|c|c|c|c|c|c|c|c|c|}
\hline \multirow{3}{*}{\multicolumn{2}{|c|}{$\begin{array}{c}\text { Water supply } \\
\text { adequacy }\end{array}$}} & \multicolumn{8}{|c|}{ TECS } & \multirow{2}{*}{\multicolumn{2}{|c|}{ Total }} \\
\hline & & \multicolumn{2}{|c|}{$\begin{array}{c}\text { SMK Sultan } \\
\text { Yahya Petra } 2\end{array}$} & \multicolumn{2}{|c|}{$\begin{array}{c}\text { SMK Manek } \\
\text { Urai Lama }\end{array}$} & \multicolumn{2}{|c|}{ SMK Laloh } & \multicolumn{2}{|c|}{$\begin{array}{c}\text { SK Kuala } \\
\text { Gris }\end{array}$} & & \\
\hline & & $\mathrm{N}$ & $\%$ & $\mathrm{~N}$ & $\%$ & $\mathrm{~N}$ & $\%$ & $\mathrm{~N}$ & $\%$ & $\mathrm{~N}$ & $\%$ \\
\hline \multirow[t]{2}{*}{ Drinking } & Yes & 12 & 14.12 & 59 & 44.70 & 8 & 34.78 & 4 & 6.67 & 83 & 27.67 \\
\hline & No & 73 & 85.88 & 73 & 55.30 & 15 & 65.22 & 56 & 93.33 & 214 & 71.33 \\
\hline \multirow[t]{2}{*}{ Cooking } & Yes & 27 & 31.76 & 63 & 47.73 & 9 & 39.13 & 7 & 11.67 & 106 & 35.33 \\
\hline & No & 58 & 68.26 & 69 & 52.27 & 14 & 60.87 & 53 & 88.33 & 194 & 64.67 \\
\hline \multirow[t]{2}{*}{ Bathing } & Yes & 44 & 51.76 & 89 & 67.42 & 11 & 47.83 & 9 & 15.00 & 153 & 51.00 \\
\hline & No & 41 & 48.24 & 43 & 32.58 & 12 & 52.17 & 51 & 85.00 & 147 & 49.00 \\
\hline \multirow[t]{2}{*}{ Washing } & Yes & 72 & 84.71 & 86 & 65.15 & 1 & 4.35 & 7 & 11.67 & 166 & 55.33 \\
\hline & No & 13 & 15.29 & 46 & 34.85 & 22 & 95.65 & 53 & 88.33 & 134 & 44.67 \\
\hline
\end{tabular}

Note. $\mathrm{N}=$ frequency, $\%=$ percentage

From the results of the cross-tabulation tests, it can be concluded that water supplies were insufficient for female compared to male, for all domestic activities. According to Makoni et al. (2004), different genders do have different assessments with regard to water use. The findings also indicate that water supplies were insufficient for carrying out domestic activities at the TECs during floods for the married couples. This is because household size is one of the factors that affect water demand positively (Hoffmann et al., 2006; Schleich \& Hillenbrand, 2009; Arbués et al., 2010). The married respondents required more clean water supplies to cater for their family members than the single and widowed respondents. In terms of TECs, it is clear that there were not enough water supplies at the TECs, especially with regard to the bottled/mineral water aid. This difficulty occurred at the TECs of SMK Laloh and SK Kuala Gris where the water supplies were not enough for drinking, cooking, bathing and washing, while the water supplies were not enough for drinking and cooking at the TECs of SMK Sultan Yahya Petra 2 and SMK Manek Urai Lama.

Therefore, a flood disaster management that prioritises on the management of water supply during floods, plays an important role in ensuring flood victims at TECs receive a continuous clean water supply assistance. Management of water supply during floods can be implemented with helps from various parties working together to improve the efficiency in the distribution of clean water supplies to TECs which often experience shortage in water supplies such as SMK Laloh and SK Kuala Gris. The existence of an effective disaster management can help mitigate its impact (Eden \& Matthews, 1997; Ibrahim, 2007). In addition, the step to enhance access to alternative water resources such as rainwater to be used during floods is also one of the approaches that can be 
practiced by the authorities to ensure that victims receive sufficient water at TECs. Rainwater resources can be collected through rainwater harvesting method. Rainfall harvesting is an alternative step in providing water during an emergency (CEHI, 2009). According to Wulandari and Sirait (2008), rainwater is an alternative source of clean water supply in Jakarta, Indonesia during floods to reduce the impact on the population, especially in terms of health. Nashima et al. (2013) emphasis that rainwater is a very cheap and uncontaminated source. Hence, taking no effective measures can lead to a deterioration in health and affect the domestic activities of flood victims at TECs in the future.

\section{Conclusion}

Water supply is an important resource for the Kuala Krai flood victims to carry out domestic activities at the TECs such as drinking and cooking. Thus, the authorities need to improve the efficiency of flood disaster management in the aspect of water supply assistance so that the water distribution activities to the TECs can be implemented systematically and continuously. Furthermore, the search efforts for alternative water resources such as rainwater through rainwater harvesting systems also can be implemented to increase access to water at the TECs. An efficient management of flood disaster and alternative water will be able to cater for the water supply needs of the flood victims at the TECs in Kuala Krai and subsequently able to address water supply problems during floods.

\section{Acknowledgement}

The authors would like to thank and acknowledge the Sultan Idris Education University and Malaysia Ministry of Higher Education for the financial support with the research grant (Research code: 20150191-106-41) partly used in this article.

\section{Corresponding Author}

Koh Liew See

Department of Geography and Environment, Faculty of Human Sciences, Sultan Idris Education University, 35900 Tanjong Malim, Perak, Malaysia

Email: kohliewsee89@gmail.com

\section{References}

Abbas, H. B., \& Routray, J. K. (2014). Vulnerability to flood-induced public health risks in Sudan. Disaster Prevention and Management, 23(4), 395-419.

Arbués, F., Villanúa, I., \& Barberán, R. (2010). Household size and residential water demand: An empirical approach. Australian Journal of Agricultural and Resource Economics, 54(1), 61-80.

Bariweni, P. A., Tawari, C. C., \& Abowei, J. F. N. (2012). Some environmental effects of flooding in the Niger Delta Region of Nigeria. International Journal of Fisheries and Aquatic Sciences, 1(1), 3546.

CEHI (Caribbean Environmental Health Institute). (2009). Rainwater catch it while you can: $A$ handbook on rainwater harvesting in the Caribbean. United Nations Environment Programme (UNEP).

Chua, Y. P. (2014). Kaedah dan statistik penyelidikan buku 1: Kaedah penyelidikan (3rd ed.). McGrawHill.

eBanjir Negeri Kelantan. (2015). Laporan catatan aras air tertinggi mengikut tempat. Retrieved from http://ebanjir.kelantan.gov.my/p_parpt01.php 
INTERNATIONAL JOURNAL OF ACADEMIC RESEARCH IN BUSINESS AND SOCIAL SCIENCES

Vol. 10, No. 10, 2020, E-ISSN: 222 2-6990 @ 2020 HRMARS

Eden, P., \& Matthews, G. (1997). Disaster management in libraries. Facilities, 15(1/2), 42-49.

Few, R., Tran, P. G., \& Hong, B. T. T. (2004). Living with floods: Health risks and coping strategies of the urban poor in Vietnam. Retrieved from https://www.uea.ac.uk/polopoly_fs/1.19249!study reportfinal.pdf

Hoffmann, M., Worthington, A., \& Higgs, H. (2006). Urban water demand with fixed volumetric charging in a large municipality: The case of Brisbane, Australia. The Australian Journal of Agricultural and Resource Economics, 50, 347-359.

Ibrahim, M.S. (2007). Disaster types. Disaster Prevention and Management: An International Journal, 16(5), 704-717.

Jabatan Perancangan Bandar dan Desa. (2011). Draf rancangan tempatan Jajahan Kuala Krai 2020: Jilid I penyataan bertulis. Jabatan Perancangan Bandar dan Desa.

Kamarul, B. A., Shaik, A. W. F., Nik, N. A. R. H., Nik, N. M. A., Tuan, T. K. H., Abu, M. N. Y., \& Mohd, A. M. R. (2015). The record-setting flood of 2014 in Kelantan: Challenges and recommendations from an emergency medicine perspective and why the medical campus stood dry. Malaysia Journal of Medical Sciences, 22(2), 1-7.

Kementerian Kesihatan Malaysia. (2015). Siaran media: Tindakan kementerian kesihatan menangani banjir 19 Januari 2015. Retrieved from https://kpkesihatan.com/2015/01/19/siaran-mediatindakan-kementerian-kesihatan-menangani-banjir-19-januari-2015/

Krejcie, R. V., \& Morgan, D. W. (1970). Determining sample saiz for research activities. Educational and Psychological Measurement, 30, 607-610.

Linscott, A. . (2007). Natural disasters - A microbe's paradise. Clinical Microbiology New Letter, 29(8), 57-62.

Mahmood, A. (2004). Flood impacts on rural water supply and sanitation and mitigation options. Proceedings of the National Workshop on Options for Flood Risk and Damage Reduction in Bangladesh.

Makoni, F. S., Manase, G., \& Ndamba, J. (2004). Patterns of domestic water use in rural areas of Zimbabwe, gender roles and realities. Physics and Chemistry of the Earth, 29(15), 1291-1294.

Nashima, F. P., Hipondoka, M., Liyambo, I., \& Hambia, J. (2013). The potential of rainwater harvesting: A case of the city of Windhoek, Namibia. Journal of Water Resources and Ocean Science, 2(6), 170-174.

Schleich, J., \& Hillenbrand, T. (2009). Determinants of residential water demand in Germany. Ecological Economics, 68, 1756-1769.

Sharad, K. J., Pushpendra, K. A., \& Vijay, P. S. (2007). Chapter 18: Problems related to water resources management in India. In Hydrology and Water Resources of India (pp. 871-936).

Shimi, A. C., Parvin, G. A., Biswas, C., \& Shaw, R. (2010). Impact and adaptation to flood: A focus on water supply, sanitation and health problems of rural community in Bangladesh. Disaster Prevention and Management: An International Journal, 19(3), 298-313.

Wan, N. T. W. H., Hidayati, Z. N., \& Nazir, A. M. (2015). Knowledge sharing and lesson learned from flood disaster: A case in Kelantan. Journal of Information Systems Research and Innovation, 9(2), 1-10. 